JURNALYOGA DAN KESEHATAN

JURUSAN YOGA KESEHATAN

FAKULTAS BRAHMA WIDYA

IHDN DENPASAR
Vol. 3 No. 1 Maret 2020

ISSN : 2621-0185 (Cetak)

http://ejournal.ihdn.ac.id/index.php/jyk

\title{
Yoga Gembira Bagi Lansia Hipertensi
}

\author{
Ni Made Sinarsari \\ Program Studi Kesehatan Ayurweda UNHI Denpasar \\ email : sinarsari73@gmail.com
}

Diterima tanggal 10 November 2019, diseleksi tanggal 11 Desember 2019, dan disetujui tanggal 30 Desember 2019

\section{ABSTRACT}

Elderly is a natural process that occurs in every human being. There is a decrease in the network's ability to repair itself, maintain function so that it is unable to withstand infections and damage that occurs. The elderly have several problems, one of which is hypertension. Hypertension in the elderly 140/90 $\mathrm{mmHg}$. Hypertension in the elderly is largely isolated systolic hypertension (HST). Hypertension occupies $87 \%$ of cases in people aged over 50 years. Efforts related to handling hypertension in the elderly include conventional, traditional approaches. One effort that can be done is to do balance exercises (yoga). Yoga is very important for the elderly in improving the quality of life. Regular exercise can improve physical health, mental health, social relationships, reduce the risk of abusers and maintain elderly bodily functions

Keywords: Yoga, Elderly, Hypertension.

\section{ABSTRAK}

Lanjut usia (lansia) merupakan proses yang alami yang terjadi pada setiap manusia. Terdapatan penurunan kemampuan jaringan untuk memperbaiki diri, mempertahankan fungsi sehingga tidak mampu bertahan terhadap infeksi dan kerusakan yang terjadi. Lansia memiliki beberapa masalah salah satunya penyakit hipertensi. Hipertensi pada lansia 140/90 $\mathrm{mmHg}$. Hipertensi pada lansia sebagian besar merupakan hipertensi sistolik terisolasi (HST). Hipertensi menempati $87 \%$ kasus pada orang yang berumur diatas 50 tahun. Upaya terkait penanganan hipertensi pada lansia meliputi pendekatan secara konvensional, tradisional. Salah satu upaya yang dapat dilakukan adalah melakukan latihan keseimbangan (yoga). Yoga sangat penting bagi lansia dalam meningkatkan kualitas hidup. Latihan yang teratur dapat meningkatkan kesehatan fisik, mental, hubungan sosial, mengurangi resiko penyaki dan memelihara fungsi tubuh lansia

\section{Keywords: Yoga, Lansia, Hipertensi.}

\section{PENDAHULUAN}

Hipertensi merupakan penyakit tidak menular serta menjadi masalah kesehatan secara global. Hipertensi adalah suatu keadaan dimana tekanan darah sistolik $\geq 140 \mathrm{mmHg}$ dan tekanan diastolik $\geq 90 \mathrm{mmHg}$ pada dua kali pengukuran dengan selang waktu lima menit dalam keadaan istirahat. Pada umumnya hipertensi tidak memberikan keluhan dan gejala yang khas sehingga 
banyak penderita yang tidak menyadarinya Bedasarkan data WHO pada tahun 2014 terdapat sekitar 600 juta penderita hipertensi di seluruh dunia. Prevalensi tertinggi terjadi di wilayah Afrika yaitu sebesar $30 \%$. Prevalensi terendah terdapat di wilayah Amerika sebesar $18 \%$. Secara umum, laki-laki memiliki prevalensi hipertensi yang lebih tinggi dibandingkan wanita. Riset KESehatan DASar pada tahun 2013 mencatat prevalensi hipertensi di Indonesia sebesar 25,8 \%, dengan prevalensi tertinggi terdapat di Bangka Belitung (30,9\%), diikuti Kalimantan Selatan (30,8\%), Kalimantan Timur (29,6\%) dan Jawa Barat $(29,4 \%)$.

Hipertensi adalah penyakit nomor tiga dari 10 penyakit yang mempunyai persentase besar dan yang sering di jumpai pada usia lanjut. Berdasarkan data WHO dari 50\% penderita hipertensi yang diketahui hanya $25 \%$ yang mendapat pengobatan, dan hanya $12,5 \%$ yang diobati dengan baik (adequately treatedcases). Berdasarkan Survei Kesehatan Rumah Tangga (SKRT) tahun 2001, kematian akibat penyakit jantung dan pembuluh darah di Indonesia sebesar 26,3\%, sedangkan data kematian di rumah sakit tahun 2005 sebesar 16,7 (Ruhyana, 2007). Di Indonesia banyaknya penderita hipertensi diperkirakan 15 juta orang tetapi hanya $4 \%$ yang merupakan hipertensi terkontrol. Prevalensi 6-15\% pada orang dewasa, 50\% diantaranya tidak menyadari sebagai penderita hipertensi sehingga mereka cenderung untuk menjadi hipertensi berat karena tidak menghindari dan tidak mengetahui faktor risikonya, dan 90\% merupakan hipertensi esensial (Amiruddin, 2007). Hipertensi merupakan "silent killer" sehingga menyebabkan fenomena gunung es. Prevalensi hipertensi meningkat dengan bertambahnya usia. Kondisi patologis ini jika tidak mendapatkan penanganan secara cepat dan secara dini maka akan memperberat risiko. Akibat yang terjadi jika hipertensi tidak segera ditangani adalah otak (menyebabkan stroke), mata (menyebabkan retinopati hipertensi dan dapat menimbulkan kebutaan), jantung (menyebabkan penyakit jantung koroner termasuk infark jantung dan gagal jantung), ginjal (menyebabkan penyakit ginjal kronik, gagal ginjal terminal).

Angka insiden hipertensi sangat tinggi terutama pada populasi lanjut usia (lansia), usia di atas 60 tahun, dengan prevalensi mencapai 60\% sampai 80\% dari populasi lansia. Diperkirakan dua dari tiga lansia mengalami hipertensi. Keadaan ini didukung oleh penelitian yang menunjukkan bahwa prevalensi hipertensi meningkat seiring dengan pertambahan usia. Pada sebuah penelitian di SaoPaulo didapatkan prevalensi hipertensi pada lansia sebesar 70\% dari jumlah populasinya. Keadaan serupa juga ditemukan pada penelitian yang dilakukan di China, dimana pada penelitian tersebut hipertensi ditemukan pada $53 \%$ populasi lansia.

Hipertensi sebagai sebuah penyakit kronis dipengaruhi oleh berbagai faktor. Faktor resiko terjadinya hipertensi terbagi dalam faktor risiko yang tidak dapat dimodifikasi dan faktor risiko yang dapat dimodifikasi. Faktor risiko yang tidak dapat dimodifikasi seperti keturunan, 
jenis kelamin, ras dan usia. Sedangkan faktor risiko yang dapat dimodifikasi yaitu obesitas, kurang berolahraga atau aktivitas, merokok, alkoholisme, stress, dan pola makan.

Usaha pencegahan juga bermanfaat bagi penderita hipertensi agar penyakit tidak menjadi lebih parah, tentunya harus disertai pemakaian obat - obatan yang ditentukan oleh dokter. Agar terhindar dari komplikasi fatal hipertensi, Harus diambil pencegahan tindakan yang baik, antara lain dengan cara pembatasan konsumsi, maksimal dua gram garam dapur untuk diet setiap hari. Menghindari kegemukan (obesitas) dengan menjaga berat badan normal atau tidak berlebihan. Membatasi konsumsi lemak dilakukan agar kadar kolesterol darah tidak terlalu tinggi, kadar kolesterol darah yang tinggi dapat mengakibatkan terjadinya endapan kolesterol dalam dinding pembuluh darah, lama kelamaan jika endapan kolesterol bertambah akan menyumbat pembuluh nadi dan mengganggu peredaran darah. Olahraga secara teratur dapat menyerap atau menghilangkan endapan kolesterol pada pembuluh nadi. Olahraga yang dimaksud adalah latihan menggerakkan semua sendi dan otot tubuh ,yoga (latihan isotonik atau dinamik), seperti gerak jalan, berenang, naik sepeda. Tidak dianjurkan melakukan olahraga yang menegangkan seperti tinju, gulat atau angkat besi, karena latihan yang berat bahkan dapat menimbulkan hipertensi, makan buah dan sayuran segar karena mengandung banyak vitamin dan mineral, buah yang banyak mengandung mineral kalium dapat membantu menurunkan tekanan darah, tidak merokok dan tidak minum alkohol (Gunawan, 2010).

Latihan yoga juga menstimulasi pengeluaran hormon Endorphin. Endorphin adalah neuropeptide yang menghasilkan tubuh pada saat relaks/tenang. Endorphin dihasilkan di otak dan susunan syaraf tulang belakang. Hormon ini dapat berfungsi sebagai obat penenang alami yang diproduksi otak yang menyalurkan rasa nyaman dan meningkatkan kadar endorphin dalam tubuh untuk mengurangi tekanan darah tinggi. Olahraga terbukti dapat meningkatkan kadar bendorphin empat sampai lima kali di dalam darah. Sehingga, semakin banyak melakukan latihan maka akan semakin tinggi pula kadar b-endorphin. Ketika seseorang melakukan latihan, maka bendorphin akan keluar dan ditangkap oleh reseptor didalam hiphothalamus dan system limbik yang berfungsi untuk mengatur emosi. Peningkatan b-endorphin terbukti berhubungan erat dengan penurunan rasa nyeri, peningkatan daya ingat, memperbaiki nafsu makan, kemampuan seksual, tekanan darah dan pernafasan (Sindhu, 2006).

\section{PEMBAHASAN}

\subsection{Gambaran Umum Hipertensi pada Lansia}

Pengertian hipertensi pada lansia adalah penyakit dimana tekanan darah batas atas (systole) lebih dari $140 \mathrm{mmHg}$ dan tekanan darah batas bawah (diastole) lebih dari $90 \mathrm{mmHg}$ 
(Maryam, 2008). Hipertensi adalah tekanan darah sistolik $\geq 140 \mathrm{mmHg}$ dan tekanan darah diastolik $\geq 90 \mathrm{mmHg}$, atau bila pasien memakai obat anti hipertensi (Mansjoer, 2010). Hipertensi adalah tekanan darah tinggi yang bersifat abnormal dan diukur paling tidak pada tiga kesempatan yang berbeda (Ardiansyah, 2012).

Hipertensi adalah suatu keadaan di mana seseorang mengalami peningkatan tekanan darah di atas normal yang ditunjukkan oleh angka systolic (bagian atas) dan angka bawah (diastolic) pada pemeriksaan tensi darah menggunakan alat pengukur tekanan darah baik yang berupa cuff air air raksa (sphygmomanometer) ataupun alat digital lainnya (Pudiastuti, 2013). Hipertensi terjadi akibat adanya perubahan struktur dan fungsi pada sistem pembuluh darah perifer yang bertanggung jawab pada perubahan tekanan darah. Perubahan tersebut meliputi aterosklerosis,yaitu menghilangnya elastisitas jaringan ikat dan menurunnya relaksasi otot polos pembuluh darah sehingga mengakibatkan penurunan kemampuan daya regang dan distensi pembuluh darah. Hal ini menyebabkan aorta dan arteri besar berkurang kemampuannya untuk mengakomodasi volume darah yang dipompa oleh jantung sehinggatekanan darah dan nadi istirahat menjadi tinggi.

Berdasarkan penyebabnya hipertensi dibagi menjadi dua golongan, yaitu :

a. Hipertensi esensial atau hipertensi primer yang tidak diketahui penyebabnya, disebut juga hipertensi idiopatik. Terdapat sekitar 95\% kasus. Banyak faktor yang mempengaruhinya seperti genetik, lingkungan, hiperaktivitas susunan saraf simpatis, sistem reninangiotensin, defek dalam ekskresi natrium, peningkatan Natrium dan Calium intraselular, dan faktor-faktor yang meningkatkan risiko, seperti obesitas, alkohol, merokok serta polisitemia.

b. Hipertensi sekunder atau hipertensi renal. Terdapat sekitar 5\% kasus. Penyebab spesifiknya diketahui, seperti penggunaan estrogen, penyakit ginjal, hipertensi vaskuler renal, hiper aldosteronisme primer, dan sindrom cushing, feokromositoma, koarktasio aorta, hipertensi yang berhubungan dengan kehamilan dan lain-lain (Mansjoer, 2010).

Penanganan hipertensi menurut Susilo \& Wulandari (2011) dalam Hermanto (2014) adalah dengan cara mengatasi keadaan obesitas atau menurunkan berat badan, mengurangi asupan garam ke dalam darah, menciptakan keadaan rileks seperti meditasi, yoga, atau hypnosis yang mengontrol sistem saraf untuk mengendalikan tekanan darah, melakukan olah raga secara rutin, berhenti merokok, dan berhenti mengkonsumsi alcohol.

Penatalaksanaan hipertensi diberikan dengan pemberian obat obatan dan tanpa obat. Kondisi ini dapat dikendalikan dengan melakukan aktivitas fisik dalam bentuklatihan /olahraga secara teratur. Olahraga yang dilakukan secara teratur dapat menghasilkan suatu respon 
terhadap kardiovaskuler, yakni penurunan tekanan darah dan denyut nadi istirahat secara bermakna. Latihan fisik akan memberikan efek akut pada tubuh yang mempengaruhi sistem otot, sistem hormonal, sistem peredaran darah dan pernafasan, sistem pencernaan, metabolisme, dan sistem pembuangan. Olahraga yang cukup dapat menurunkan kecemasan, stres, dan tingkat depresi. Penurunan tersebut akan menstimulasi kerja sistem saraf perifer terutama parasimpatis yang menyebabkan vasodilatasi penampang pembuluh darah akan mengakibatkan terjadinya penurunan tekanan darah baik sistolik maupun diastotik. yoga merupakan suatu olahraga yang dapat menurunkan tekanan darah. Salah satu aktifitas olahraga yang dapat dilakukan adalah yoga .yoga adalah sebuah aktivitas di mana seseorang memusatkan seluruh pikiran untukmengontrol panca inderanya dantubuhnya secarakeseluruhan. Hal ini menyebabkan seseorang tersebut dapat mengendalikan, mengatur, dan berkonsentrasi untuk menyelaraskan tubuh, jiwa,danpikiran kita. Selain itu, yoga dapat melancarkan aliran oksigen di dalam tubuh.Yoga adalah suatu mekanisme penyatuan dari tubuh (body), pikiran (mind), dan jiwa (soul).Yoga mengkombinasikan antara teknik bernafas, relaksasi, dan meditasi serta latihan pereganagan yoga gembira hipertensi.

Yoga merupakan suatu mekanisme penyatuan dari tubuh, pikiran dan jiwa. Yoga mengkombinasikan antara teknik bernapas, relaksasi dan meditasi serta latihan peregangan (Jain, 2011). Yoga dianjurkan pada penderita hipertensi, karena yoga memiliki efek relaksasi yang dapat meningkatkan sirkulasi darah yang lancar, mengindikasikan kerja jantung yang baik (Ridwan, 2009). Kombinasi antara yoga, meditas dan pemantauan kondisi tubuh menggunakan peralatan elektronik telah membuat $25 \%$ dari pasien penderita tekanan darah tinggi berhenti mengkonsumsi obat dan yang 35\% mulai menguranginya (Jain, 2011).

Ada berbagai macam jenis latihan yoga yang intinya menggabungkan antara teknik bernapas (pranayama), relaksasi dan meditasi serta latihan peregangan, yoga gembira bagi lansia hipertensi adalah jenis yoga dalam dikhususkan untuk menurunkan tekanan darah pada lansia. Bernapas adalah suatu tindakan yang otomatis tanpa harus diperintah untuk melakukannya. Tetapi, jika kita bernapas dengan cepat dan dangkal akan mengurangi jumlah oksigen yang tersedia dan otak akan bereaksi terhadap hal ini dengan panik. Bagian dari proses adalah peningkatan denyut jantung dan peningkatan tekanan darah. Dengan mengatur napas menjadi lebih pelan dan dalam akan membuat peregangan pada otot-otot tubuh. Hal ini menyebabkan tubuh dan pikiran menjadi lebih relaks, nyaman dan tenang yang membuat penurunan pada tekanan darah ( Jain, 2011) pranayama (teknik bernapas) pada yoga berfungsi untuk menenangkan pikiran dan tubuh yang membuat detak jantung lebih tenang sehingga tekanan darah dan produksi hormon adrenalin menurun. Hal ini sesuai dengan jurnal yang dikemukakan 
oleh Cramer., et al., (2014) dengan judul “ Yoga For Hypertension” bahwa pemberian yoga yang dilakukan secara rutin, yaitu selama 8 minggu, dapat berpengaruh secara signifikan terhadap perubahan tekanan darah pada penderita hipertensi. Selain itu menurut jurnal yang dikemukakan oleh Hagins.,,et.al (2013) yang berjudul " Effectiveness Of Yoga For Hypertension" dengan menggabungkan 3 unsur dari latihan yoga (postur, meditasi, dan pernafasan) yang melibatkan 18 orang dewasa dengan hipertensi, dapat menurunkan tekanan darah sitolik $7 \mathrm{mmHg}$, dan tekanan diastolik $5 \mathrm{mmHg}$.

Yoga merupakan salah satu pilihan untuk meningkatkan kebugaran dan menurunkan lemak tubuh. Yoga bersifat aerobik,sehingga memicu kerja jantung dan paru dapat memenuhi kriteria continue, rhytmical, interval, progresif, dan endurance (CRIPE) dan bila melakukan yoga secara terus-menerus akan menjaga dan meningkatkan kebugaran tubuh. yoga yang teratur dan terukur dapat merangsang aktivasi dari enzim lipase, yang akan memecah lemak menjadi asam lemak bebas. Proses beta oksidasi dari asam lemak bebas ini akan menghasilkan Asetil Ko-A, yang selanjutnya akan diubah menjadi air, CO2 dan ATP pada proses pembentukan energi, sehingga dengan semakin banyaknya kolesterol yang dipecah menjadi energi, maka kadar kolesterol serum juga semakin menurun. Yoga lansia merupakan latihan fisik.roso yang dapat meningkatkan curah jantung yang akan disertai meningkatnya distribusi oksigen ke bagian tubuh yang membutuhkan. Yoga dapat melemaskan pembuluhpembuluh darah, sehingga tekanan darah menurun, sama halnya dengan melebarnya pipa air akan menurunkan tekanan air. Latihan yoga juga dapat menyebabkan aktivitas saraf, reseptor hormon, dan produksi hormon-hormon tertentu menurun. Bagi penderita hipertensi yoga tetap aman dilakukan yang dapat menurunkan tekanan sistolik maupun diastolik pada orang yang mempunyai tekanan darah tinggi tingkat ringan.

Yoga akan meningkatkan efisiensi paru-paru dan kerja jantung. Latihan tersebut bermanfaat untuk meningkatkan dan mempertahankan komponen kebugaran dasar meliputi ketahanan kadiorespiratori (jantung-paru-peredaran darah), lemak tubuh, kekuatan otot dan kelenturan sendi. Kondisi tersebut dapat dicapai dengan aktivitas kebugaran untuk membantu mempertahankan fungsi-fungsi organ tubuh, terutama jantung. Disamping itu yayasan Jantung Sehat indonesia menganjurkan agar banyak bergerak, olahraga, bekerja secara fisik, atau sebagainya agar jantung tetap terpelihara dengan baik. Selama latihan akan terjadi kontrol terintegrasi pada tekanan darah. Tekanan darah dikendalikan secara refleks melalui sistem saraf otonom, khususnya sensor khusus yang berlokasi di aortic arch dan arteri karotid, yang disebut refleks baroreseptor. Baroreseptor sangat sensitif untuk mengubah tekanan arteri. 
Refleks baroreseptor berfungsi sebagai penahan (pengontrol) pada perubahan akut tekanan darah.

Berikut merupakan Gerakan Yoga Gembira bagi Lansia Hipertensi :

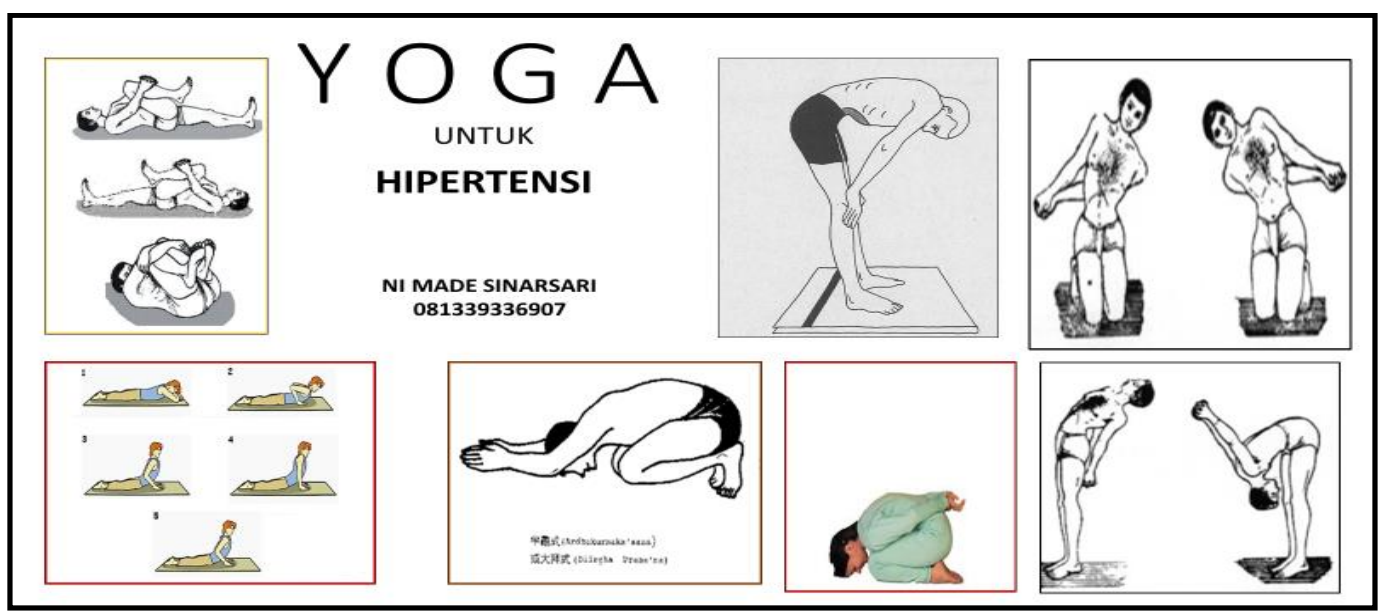

Gambar 1 : Yoga untuk Hipertensi

Sumber : Sinarsari

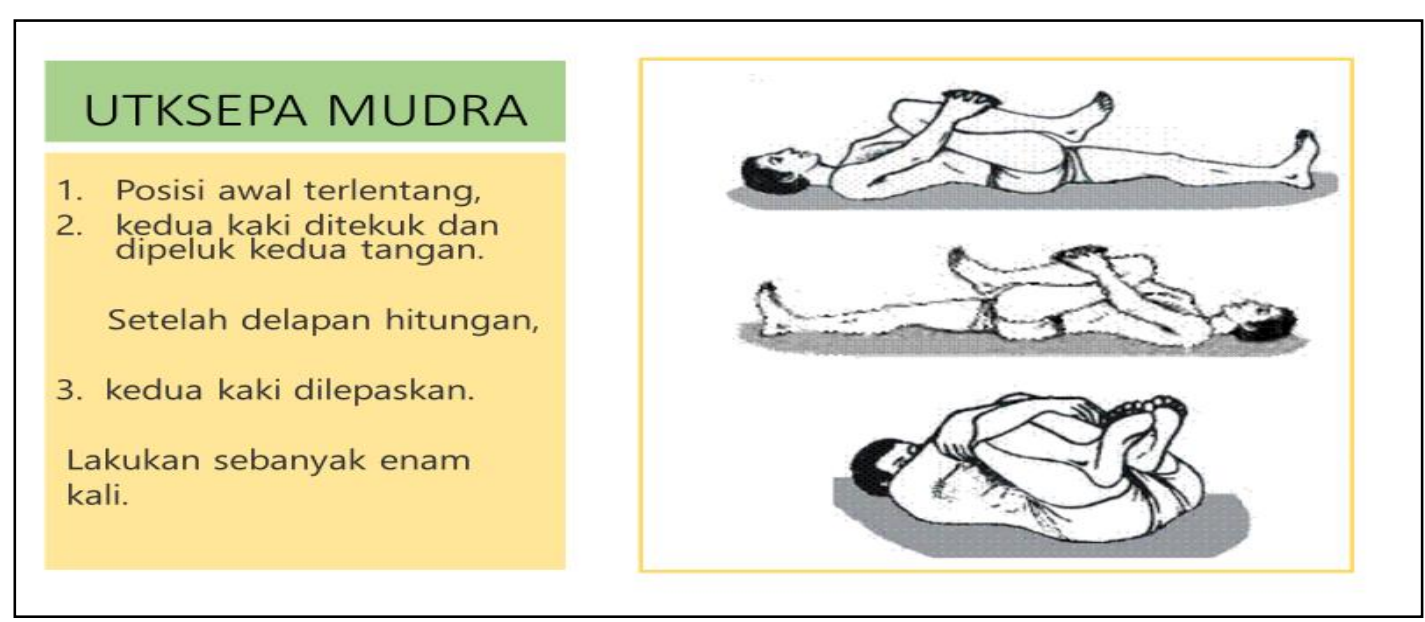

Gambar 2 : Utksepa Mudra

Sumber : Sinarsari

\section{DIIRGHA PRANAMA}

Posisi awal berlutut,

kedua tangan diangkat

dibawa ke depan dahi dan kedua tangan menempel

Lakukan ini dalam delapan hitungan

sebanyak delapan kali.

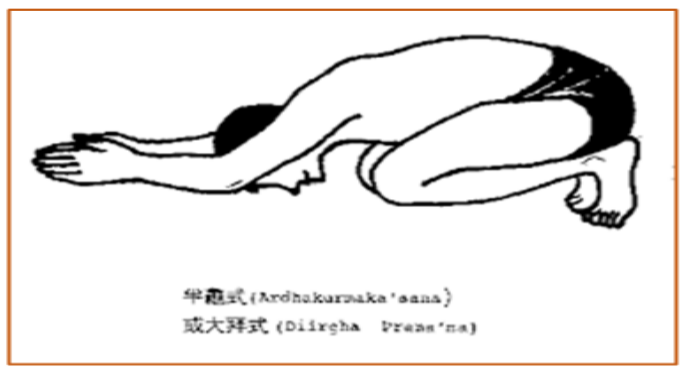

Gambar 3 : Diirgha Pranama

Sumber : Sinarsari 


\section{YOGA MUDRA}

Posisi awal bersila.

Tangan kanan lalu

menggenggam pergelangan

tangan kiri di belakang

punggung.

kepala dan badan ditarik ke depan hingga dahi menyentuh lantai.

Lakukan ini dalam delapan

hitungan sebanyak delapan kali.

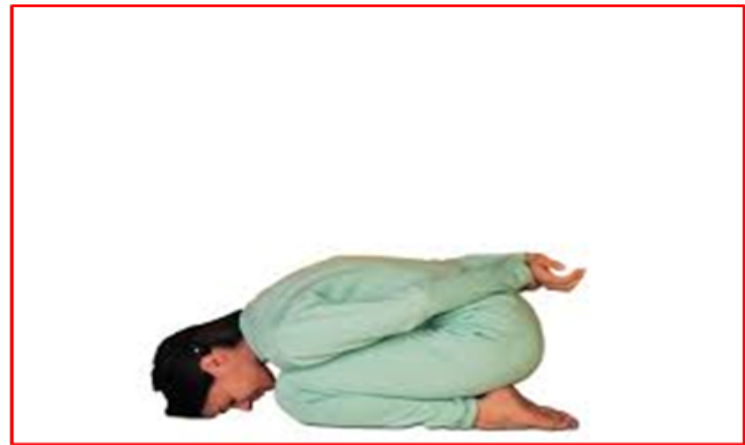

\section{Gambar 4 : Yoga Mudra}

Sumber : Sinarsari

\section{KARMASANA A}

Posisi berdiri

kedua tangan saling

menggenggam di belakang

badan.

badan ditekuk ke kiri, kanan, ke depan dan ke belakang.

Ini dilakukan dalam delapan hitungan

sebanyak delapan kali.

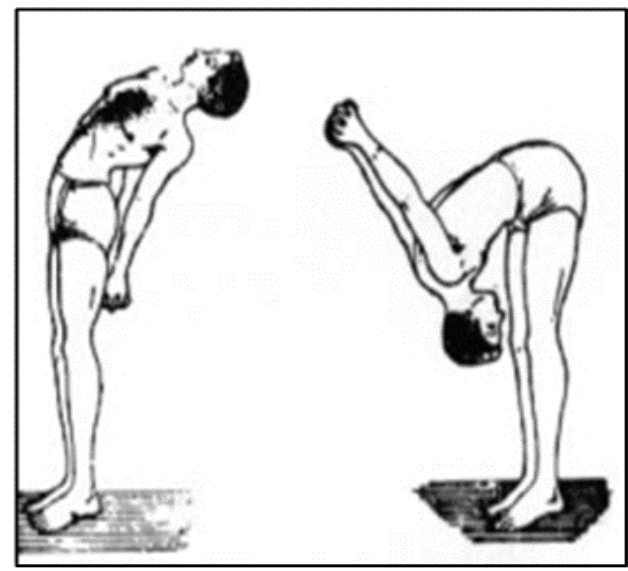

Gambar 5 : Karmasana A

Sumber : Sinarsari

\section{UDDIYANA MUDRA}

Posisi berdiri

membungkuk dengan tangan bertopang di lutut.

tarik nafas hingga perut mengempis, dan setelah itu dihembuskan.

Lakukan delapan hitungan selama delapan kali.

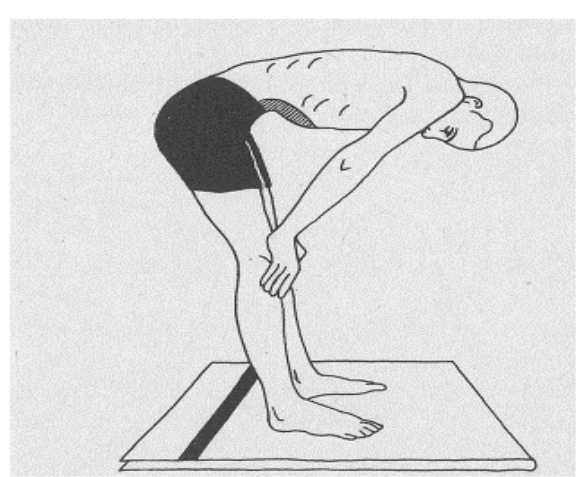

Gambar 5 : Uddiyana Mudra

Sumber : Sinarsari 


\section{PENUTUP}

Seseorang yang makin tua akan mempunyai resiko yang lebih besar terhadap penyakit hipertensi, yang diakibatkan metabolisme kalsium yang terganggu dan tidak memperhatikan diet rendah garam, serta terjadi pula penurunan fungsi organ pada sistem kardiovaskular dimana katup jantung terjadi penurunan elastisitas aorta dan arteri besar lainnya. Kegiatan fisik rohani berupa yoga akan berpengaruh menurunkan tekanan darah dengan cara melepaskan lebih banyak hormon endorphin dalam tubuh yang dapat mengatur tekanan darah agar sesuai dengan kerja normal. Yoga berpengaruh terhadap kerja paru-paru dan jantung sekaligus mempertahankan dan meningkatkan komponen kebugaran. Dan juga dapat membuat jantung tetap terpelihara dengan baik. Yoga dapat membuat tekanan darah terkontrol secara terintegrasi oleh baroreseptornya sehingga terjadi penahanan (pengontrolan) tekanan darah. merelaksasikan pembuluh-pembuluh darah sehingga aliran darah menjadi lancar dan menurunkan tekanan darahYoga juga menurunkan aktivitas saraf dan hormon sehingga produksi hormon norepinefrin menurun dan akhirmya menurunkan tekanan darah. Yoga gembira lansia hipertensi dilakukan secara teratur dan terukur serta dibutuhkan adanaya pemantauan dari instruktur yoga yang sudah tersertifikasi sebagai pengajar yoaga bagi lansia.

\section{DAFTAR PUSTAKA}

Amiruddin,Ridwan,2007. Hipertensi dan Faktor Resiko dalam Kajian Epidemiologi

Davis Leslie,2004. Cardiovascular Nursing Secret. Elsevier Mosby: USA

Gunawan,2013. Hipertensi Tekanan Darah Tinggi. Yogyakarta: Kanisius

Kemenkes Republik Indonesia. (2015). Data dan Informasi Tahun 2014 (Profil Kesehatan). Jakarta.

Maryam,R. 2008. Mengenal Usia Lanjut dan Perawatannya. Salemba Medika: Jakarta

Mansjoer,2010. Kapita Selekta Kedokteran. Jakarta: FK UI

Ruhyana,2007. Hipertensi Penyebab Utama Penyakit Jantung.

Sindhu,2014. Panduan Lengkap Yogi untuk Hidup Sehat dan Seimbang. Qanita: Bandung

Yogianto,M.2009. Hipertensi Esensial Ilmu Ajar Penyakit Dalam Jilid II Edisi V. Interen Publising: Jakarta 